交直並行送電系統における 直流パワーモジュレーションによる電力動摇抑制制御

$\begin{array}{llll}\text { 正員 } & \text { 富山藤 } & \text { 勝幸 } & \text { (閵西電力) } \\ \text { 正員 } & \text { (関西電力) } \\ \text { 正員 } & \text { 山地 } & \text { 幸司 } & \text { (四国電力) } \\ \text { 正員 } & \text { 関田 } & \text { 昌弘 } & \text { (電源開発) } \\ \text { 正員 } & \text { 後藤 } & \text { 益雄 } & \text { (日 立) }\end{array}$

\title{
Power Swing Damping Control by HVDC Power Modulation in AC/DC Hybrid Transmission System
}

\author{
Katsuyuki TOMIYAMA, Member (The Kansai Electric Power Co., Inc.) \\ Masakazu SATO, Member (The Kansai Electric Power Co., Inc.) \\ Kouji YAMAJI, Member (Shikoku Electric Power Co., Inc.) \\ Masahiro SEKITA, Member (Electric Power Development Co., Ltd.) \\ Masuo GOTO, Member (Hitachi, Ltd.)
}

This paper describes a power swing damping control by HVDC power modulation. In a hybrid system (AC transmission system and HVDC system compose a loop transmission system.), a damping control of power swing by control of HVDC power is called power modulation control. The new inter-connection by HVDC link between Shikoku and Kansai power systems composes a loop transmission system by the existing ac transmission system and the new HVDC transmission system, therefore, a power modulation control can be applicable for stabilization of ac system. In this paper, a new developed power modulation control system to damp two power swing modes occurred in $60 \mathrm{~Hz}$ inter-connected system and the neighbor power system to the HVDC converter station. Characteristics of power swing in ac system, the principle of power swing damping control by power modulation, design method of control system and results of verification tests by digital and analog simulator are described. It is shown that the developed power modulation system applied to the HVDC link is effective for damping two power swing modes.

$$
\text { キーワード：直流送電、パワーモジュレーション、連系系統、電力動摇 }
$$

\section{1.まえがき}

直流送電システムでは直流電力を高速かつ任意のパタ ーンで制御出来るので、この特長を活かして交流系の安定 化に寄与することが出来る。直流送電系統が交流送電系統 と並行する(ループを構成する) 送電系統において、直流 系の電力を制御して交流系統の電力動摇を抑制する制御 をパワーモジュレーション (Power Modulation : PN) と呼 んでいる。[1][2][3] 広域連系の一環として四国之関西 を連系する直流送電システムが計画されているが $[4][5]$ 、 この直流送電システムは現在の交流連系系統と並行送電 形態 (ループ構成) となるので前述したパワーモジュレー ション制御が可能となる。本論文では前記直流送電システ ムにパワーモジュレーション制御を適用するにあたり、新 規の課題しして（1）複数モ一ドに対する制御方式の検討

(2) 安定化制御に用いる最適な検出信号の検討と特性評 価、（3）安定化信号検出センサの性能亡実用化、をとり あげこれらを中心に検討した結果ならびに提案するパワ
ーモジュレーション制御の安定化効果をシミュレータに より評価した結果について述べる。

\section{2. 連系系統の電力動摇特性}

図 1 は $60 \mathrm{~Hz}$ 連系系統の基本構成を示す。図 1 に示す 連系系統に発生する系統間電力動摇特性を調べるため、固

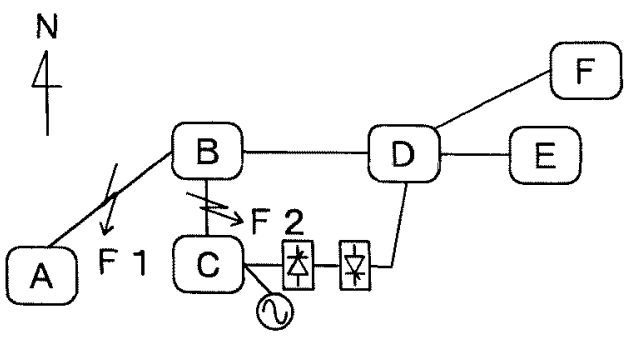

図 $160 \mathrm{~Hz}$ 系連系系統と直流送電システム

Fig. $160 \mathrm{~Hz}$ Inter-connected Power System and 1 HVDC Link 


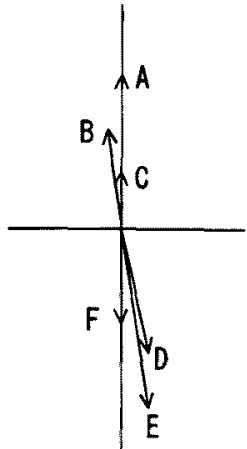

（a）長周期動摇モード

（周期 $T=3.1 \mathrm{~s}$ )

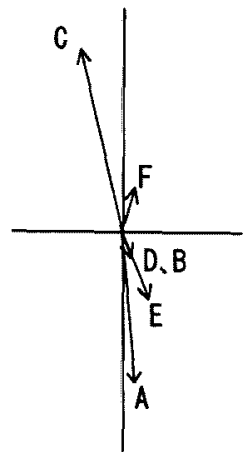

(b) C系統動摆モード

(周期 $T=1.98 \mathrm{~s}$ )
図 2 連系系統の動摇モードと代表発電機固有ベクトル

Fig. 2 Eigen Vector of Generators in Inter-Area Power Swing

有值解析を行なった。連系系統に発生する電力動摇に関す る特性を図 2 に示す。図 2 は電力動摇モードにおける各連 系系統の代表発電機の固有べクトルを表わしたものであ る。図2（a）はいわゆる長距離串形系を構成することに より生じる長周期で動摇するモードで長周期動摇モード と呼ばれており、連系系統 $\mathrm{A} か ら \mathrm{E}$ までがほぼ B D間を節 として東西間で動摇するモードを示している。図 $2(\mathrm{~b})$ はC 系統と $(\mathrm{B}+\mathrm{D})$ 系統の間に節がくる動摇モードを示 しており、ここでは前者と区別するためC系動摇モードと 呼ぶ。

前記計画の直流送電システムのパワーモジュレーショ ンではこの 2 つの動摇モードを抑制することを目的とす る。

\section{3. 直流パワーモジュレーションによる電力動摇抑制 制御}

\section{1 電力動摇抑制の原理}

電力動摇抑制の原理を考察するため图 3 に示す交直並 行送電系統を含む 2 機系を考える。图で $X_{1} 、 X_{2} 、 X_{3}$ は 交流系の送電線リアクタンスで、そのうち $\mathrm{X}_{1} 、 \mathrm{X}_{2}$ はそ れぞれ発電機のリアクタンスむ含むものとする。

図 3 において直流が一定電力運転の場合、発電機 $\mathrm{G}_{2}$ の 電力動摇を表わす運動方程式は次式で示される。（原動機 入力変化は無視する)

$$
\begin{aligned}
& \frac{M}{\omega_{0}} \frac{d^{2} \Delta \delta}{d^{2}}+\frac{D}{\omega_{0}} \frac{d \Delta \delta}{d t}+K \Delta \delta=0 \cdots(1) \\
& \omega_{0}=2 \pi \mathrm{f}_{0} \quad \mathrm{f}_{0}: \text { 基本周波数 } \\
& \mathrm{M}: \text { 慣性定数 }(\mathrm{MW} \cdot \mathrm{S} / \mathrm{NVA}) \\
& \text { D：制動トルク係数 (p. u. Power/p. u. Speed) } \\
& \mathrm{K} \text { : 同期化トルク係数 (p.u. Power/rad) } \\
& \triangle \delta: \mathrm{G}_{1}<\mathrm{G}_{2}\llcorner の \text { 位相差（rad） }
\end{aligned}
$$

次に図 3 において、直流系の電力を $\triangle \mathrm{P}_{\mathrm{DC}}$ 変化させる と、その時の $\mathrm{G}_{2}$ の出力変動に及ぼす影響は次のように考

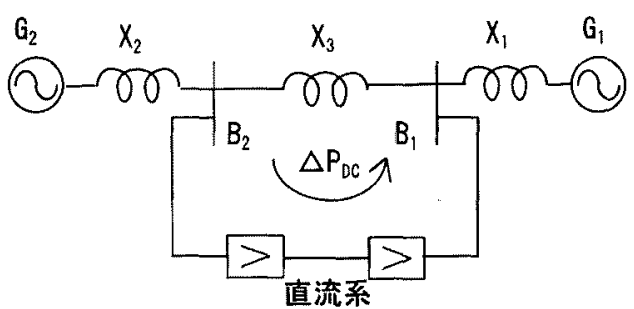

図 3 交直並行 2 機系モデル

Fig. 3 Two Machines and AC/DC Hybrid System

えられる。即ち直流電力を $\triangle \mathrm{P}_{\mathrm{D}} \mathrm{C}$ 変化させることは母線 $\mathrm{B}_{2}$ において、有効電力 $\triangle \mathrm{P}_{\mathrm{DC}}$ を吸出し、同時に母線 $\mathrm{B}_{1}$ にて有効電力 $\triangle \mathrm{P}_{\mathrm{DC}}$ を注入することと等価であるから、 今、交流系の無効電力変動や電圧変動は小さいとしてこれ を無視して有効電力のみに着目すれば、 $\triangle \mathrm{P}_{\mathrm{DC}}$ による $\mathrm{G}_{2}$ の有效出力変動 $\triangle P_{D C 2}$ は次式で示される。

$$
\begin{aligned}
\Delta P_{D C 2} & =\frac{X_{3}}{X_{1}+X_{2}+X_{3}} \cdot \Delta P_{D C} \ldots \\
& =K_{D C} \cdot \Delta P_{D C}
\end{aligned}
$$

直流を制御した時の $G_{2}$ の電力動摇を表わす運動方程式 は (1)、（2）式より

$$
\frac{\mathrm{M}}{\omega_{0}} \frac{\mathrm{d}^{2} \Delta \delta}{\mathrm{dt}^{2}}+\frac{\mathrm{D}}{\omega_{0}} \frac{\mathrm{d} \Delta \delta}{\mathrm{dt}}+\mathrm{K} \Delta \delta+\mathrm{K}_{\mathrm{DC}} \Delta \mathrm{P}_{\mathrm{DC}}=0 \cdots(3)
$$

(3)式をブロック線図で示すと図40ように表される。

図 4 からわかるように直流電力制御 $\triangle P_{D C}$ により $G_{2}$ の動摇抑制の効果を得るには $\triangle P_{D C}$ によるルクがダン ピングトルクとなるように $\triangle \mathrm{P}_{\mathrm{DC}}$ を制御すればよく、そ のために $\triangle P_{D C 2}=K_{D C} \triangle P_{D C} \Delta \omega(\triangle \dot{\delta})$ と同相成 分亡なるような位相で $\triangle P_{D C}$ を制御すればよい。

以上は 2 機系で単一モードに対する制御万法について 述べたが、多機系で複数モードに対応するには各モード毎 に制御系を組みそ扎ぞれの出力を重胃する方式を採用す れば、各モード毎の制御系は 2 機系で設計出来る。

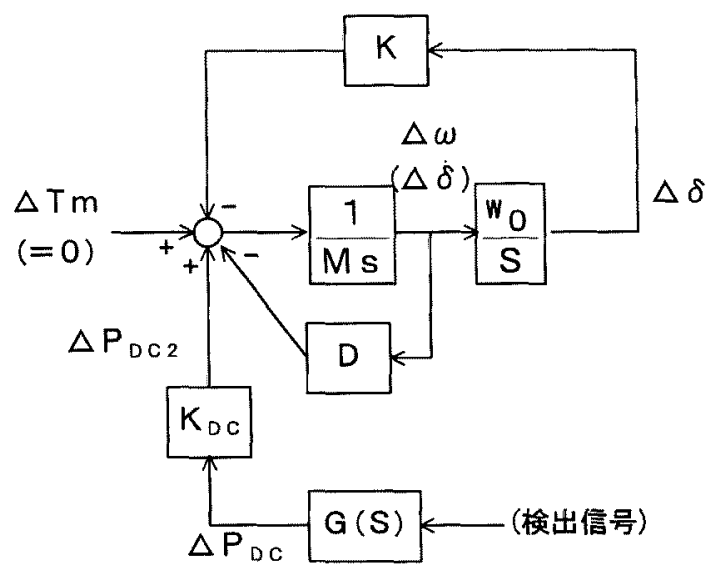

図4 電力動摇を表わすブロック線図

Fig. 4 Block Diagram Representing Power Swing 
$\Delta f$

$\Delta \omega$

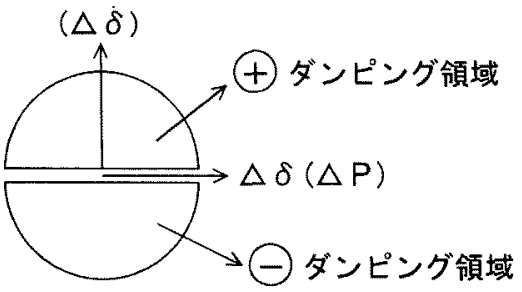

図 5 検出信号の位相関係とダンピングトルク

Fig. 5 Phaser of Input Signals and Damping Torque

\section{2 検出信号}

直流電力をパワーモジューレーション $(\mathrm{PM})$ 制御する ための検出信号としては安定化をはかる系統内の代表発 電機の回転子速度変動信号 $\triangle \omega(\triangle \dot{\delta}) 、$ 母線電殴の周波 数偏差信号 $\triangle \mathrm{f}$ 、線路潮流変動信号 $(\triangle \mathrm{P})$ 名考えられる。 これらの信号の電力動摇における位相関係は図 5 に示す ように、 $\triangle \omega(\triangle \dot{\delta})$ と $\triangle \mathrm{f}$ は同相関係にあり、 $\triangle \mathrm{P}$ は $\triangle \dot{\delta}$ より $90^{\circ}$ 位相遅れの関係にある。また、 $\triangle \omega$ 之同相成分 を有する上半円方向が正のダンピングトルクを生し、、半 円方向が負のダンピングトルクを生じる。従って図 4 にお ける検出信号に対する位相補償回路 $\mathrm{G}(\mathrm{S})$ の位相補償量

は、 $\triangle \omega(\triangle \dot{\delta}) 、 \triangle \mathrm{f}$ の場合は $0^{\circ} 、 \triangle \mathrm{P}$ の場合は $90^{\circ}$ 位相進めが必要となる。

また、 $\triangle \omega や \triangle P$ は一般には直流送電の場合には変換所 近傍では得られないので、これらの信号の検出地点から、 直流変換所まで信号伝送回路を必要とするうえに、 $\triangle \omega$ の 場合は発電機停止の事を考えると複数の発電機に検出器 を設置する必要が有り、また $\Delta P$ の場合は将来、系統構成 が変更になった時の対応が必要とされるのに対し、 $\triangle \mathrm{f} の$ 場合は変換所母線電圧より検出出来るため、信号の伝送を 必要としない等の長所を有している。反面、図 2 からわか るように、電力動摇信号は、 $\triangle \omega に$ に比し、 $\triangle \mathrm{f}$ の方が小さ く、それだけ高感度で耐ノイズ特性の良いセンサを必要と する。これらの特徽をまめると表1のようになり、総合 的に判断して、 $\triangle \mathrm{f}$ 用いる事とした。
表 1 検出信号の特徵比較

Table 1 Features of Input Signals

\begin{tabular}{|c|c|c|c|c|}
\hline 検出信号 & 位相補償 & 信号伝送 & $\begin{array}{c}\text { 含まれる } \\
\text { 動摇信号 }\end{array}$ & その他 \\
\hline$\triangle \omega$ & $0^{\circ}$ & 要 & 大 & 複数台設置 \\
\hline$\triangle \mathrm{f}$ & $0^{\circ}$ & 不要 & 小 & - \\
\hline$\triangle \mathrm{P}$ & $90^{\circ}$ 進み & 要 & 大 & 系統变化対応要 \\
\hline
\end{tabular}

\section{3 制御系の設計}

入力信号として変換所母線電压の周波数偏差 $\Delta \mathrm{f}$ を入 力とする制御ブロックとして図 6 に示すブロックを考案 した。図6に示す制御ブロックの考元方は以下の通りであ る。

(1) 両变換所母線の周波数偏差 (C 系統側の変換所母線 電圧周波数偏差を $\Delta \mathrm{f}_{\mathrm{s}} 、 \mathrm{D}$ 系統側のそれを $\Delta \mathrm{f}_{\mathrm{k}}$ ) の差 $\left(\Delta \mathrm{f}_{\mathrm{s}}-\Delta \mathrm{f}_{\mathrm{k}}\right)$ を制御ブロックの入力信号と することにより、電源脱落や負荷脱落等により全系 の周波数が偏移するような場合、この偏移量をキャ ンセル出来るため、電力動摇の抑制に無効である不 要な直流電力制御を排除出来る。

(2) 両変換所母線の周波数偏差は、図 2 に示す固有べク トルからわかるように、長周期動摇モードとC系動 摇モードともに両端で互いに逆位相の関係にあり、 差をとる事により動摇成分を拡大して検出出来る ことになる。な沶ここの場合、相手端の周波数偏差 を伝送する必要があるが、両変換所間には監視制御 用の伝送回線が付設されるので、これを利用できる ため、新たな伝送回線を設置する必要はない。

(3) 長周期動摇モードとC 系動摇モードを含む周波数偏 差の差を入力信号としこの入力信号より、長周期動 摇モード成分と C 系動摇モード成分を抽出するフ イルタを設け適切なゲインを剩じた後、両モードの 制御信号を合成（加算）して、直流系の電力指令值 を変調する。

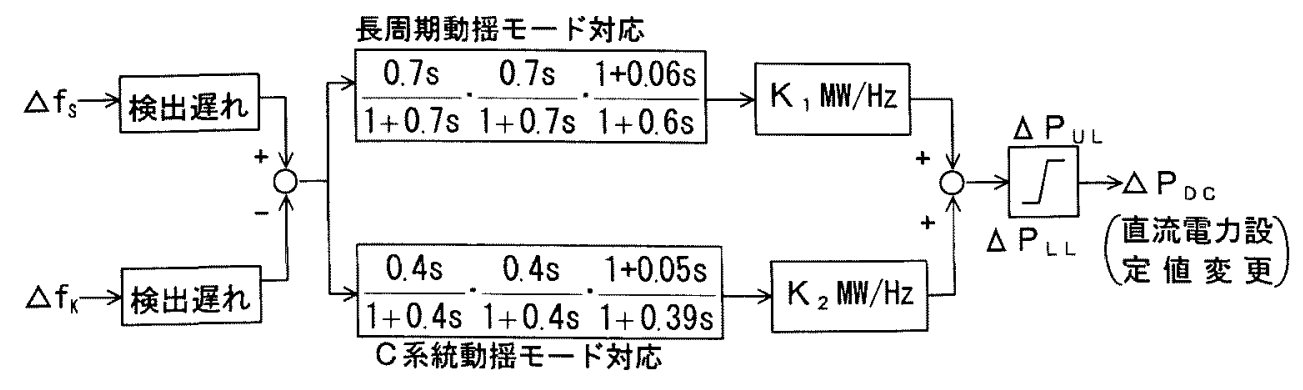

図 6 P M制御ブロック

Fig. 6 Transfer Function of PM Control 


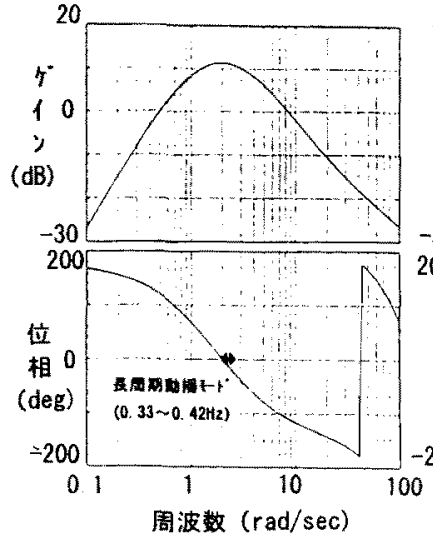

(a) 長周期動摇玉-1”用

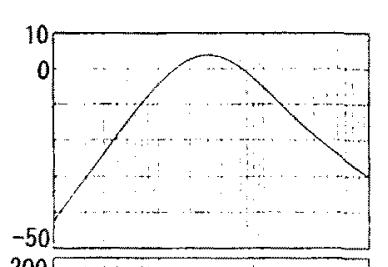

200

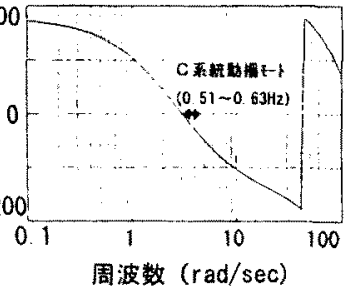

(b) C系統動摇飞-下”用
図7フィルタのボード線図

Fig. 7. Bode Diagram of Filters

(4) 動摇モード抽出用バンドパスフィル夕の設計は下記 の考え方による。

(1)長周期モード用: 検討したモデル系統において長周 期モ一ドの動摇周波数 $0.33 \sim 0.42 \mathrm{~Hz}$ でゲイ ンが最大となるバンドパスフィル夕特性を有し、0. $33 \mathrm{~Hz}$ で位相進み遅れがほぼ零になるように設計 する。フィルタのゲイン一位相特性を図 7 (a)に 示す。

(2)C系モード用:検討したモデル系統においてC系モ 一ドの動摇周波数 $0.51 \sim 0.63 \mathrm{~Hz}$ でゲインが 最大となるようバンドパスフィルタ特性を有し、0， $51 \mathrm{~Hz}$ で位相の進み遅れがほぼ零になるよう設計 する。フィルタのゲイン一位相特性を図 7 (b)に 示す。なお、 $\Delta \mathrm{f}$ 檢出痋れとして $200 \mathrm{~ms}$ 考慮 している。

（5）制御量とゲインの考え方

PMによる直流電力制御量は下記の点から制的を受 ける。1つは電灰変動である。直流電力を変化させ る亡通常運転時は調相設備を連動させ電王変動を 抑える制御を行うが、P M による直流電力制御では 基本的にほぼ正弦波状に変化させるため、ステップ 状に制御する調相制御は適切でなく、調相制御は行 わない。従って大きな電圧変動を招かない程度にP M制御量が抑えられる。もう1つの制䄪は許容過負 荷量である。定格運転している状態でPM制御をか けると過負荷運転の領域に入るので設備の短時間 過負荷容量から抑えら机る。

次に、制御ブロックのゲインは系全体の安定性を 保つ範国で入力信号の大きさに依存して決められ る。図4のブロック図からわかるようにダンピング 効果はゲインに比例するが、2つの動摇モードを対 象とした場合、同一のダンピング効果となるには対 象とする動摇モードに対応するモード慣性定数に
比例したゲインとす扎よい。この事はほぼその動 摇モードで動摇する部分系統の系統容量に比例し たゲインとなる。また、入力信号に対し、制御演算 量が大幅にリミッタにかからない程度に設定する 事も必要である。

\section{4 起動・停止制御}

PM制御は常時の安定な状態では動作する必要がなく、 電力動摇発生時に動作するのが望ましい。従ってPM制御 の起動・停止はその目的からして、電力動摇を検出して自 動的に起動し、また電力動摇の十分なる減衰を検出して自 動的に停止する方法が適している。このような考えで立案 した起動・停止制御方式を図 8 に示す。PM制御の起動条 件は P M 制御への入力信号（雨端周波数偏差の差）が、設 定值 $\triangle \mathrm{f}_{0}$ 以上で設定時間 $\mathrm{T}_{\mathrm{S}}$ 以上継続する条件である。 また停止条件は检出信号レベルが設定值 $\triangle \mathrm{f}$ 。’以下の状 態が設定時間 $T_{S_{2}}$ 以上継続する事で電力動摇が所定の值 以下に減衰した判断して停止する。この他停止条件には起 動時刻からの動作時間計時して、設定時間 $\mathrm{T}_{\mathrm{S}}$ 以上継 続すれば停止する条件も、予期しない異常現象防止のため に付加している。

これらの整定值、例えば起動条件の $\triangle \mathrm{f}_{0}$ については、 1 回線開放等の通常系統操作では動作しないレベルが考 えられ、シミュレーション結果からは $0.03 \mathrm{~Hz}$ 程度が得 られている。停止側の整定值は起動側と拹調をとり $\Delta \mathrm{f}$ 。 より小さい $\Delta \mathrm{f}_{0}{ }^{\prime}$ に設定する。

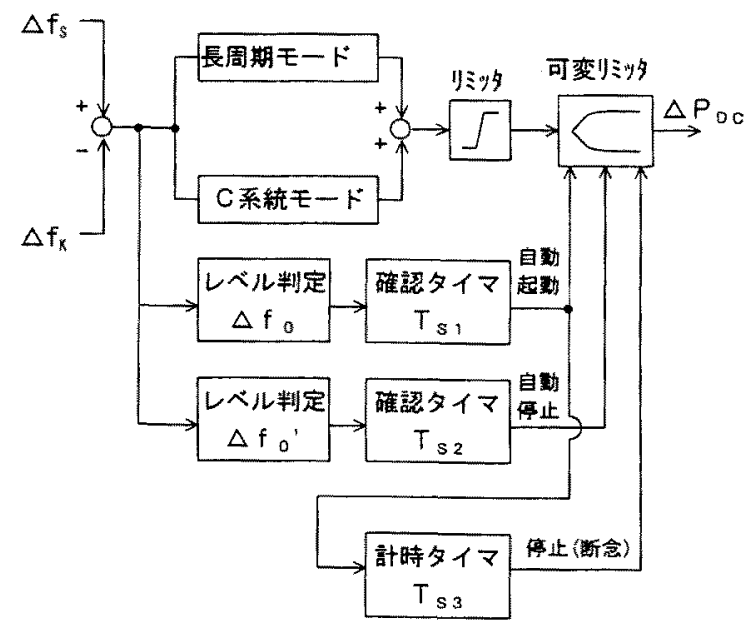

図 8 P M制御自動起動・停止方式

Fig. 8 Self Start and Stop Scheme of Pl Control

\section{4. 動作検証}

4. 1 ディジタルシミュレーションによる効果評価 3章で述べた制御系に基づき $\mathrm{PM}$ 制御を行なった時の 動摇抑制効果をディジタルシミュレーションにより䛨洒 した。動摇扸制効果の評価として、PM制御の有無のケ一 


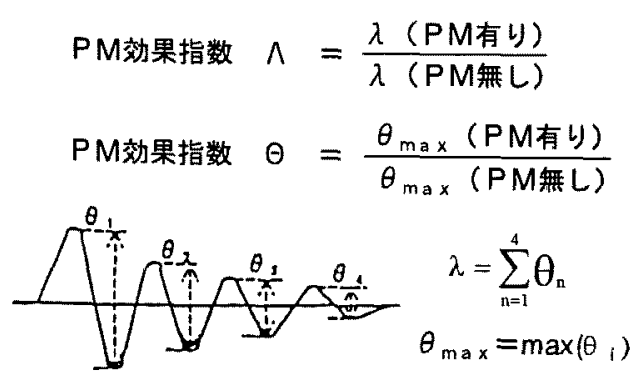

図 9 PM効果指数

Fig. 9 Coefficient of PN Effect

スにつき、各動摇モードで動摇する代表発電機の位相角変 動を図 9 に示すように 4 周期分合計してその減少率を指 数とする効果指数 $\Lambda$ 、動摇第 1 波の減少率を指数とする効 果指数 $\Theta$ 新たに導入して行なった。動摇抑制の効果評值 として减衰振動の減衰比や減衰率を 2 つ振幅の比から 求めて絶対評価を行う方法があるが、波形が数式で表して exp $(-\lambda t)$ の形状となっている場合は正しく評価出 来るが、過渡現象が重轠された場合はこの方法では正しい 評価とならない。即ち、振動波形のどの振幅を用いるかに より結果が大きく異なって来るからである。そこで図 $9 に$ 示すような複数の振幅を用い、かつPMの有無による相対 評価法を用いる事にした。安定化効果の評価は60 Hz 系 全体を95機で模擬した系統で行った。解析に用いた 95 機系は図 1 に示す連系系統を $\mathrm{A}(2$ 機)、B $(8$ 機)、C $(29$ 機)、 $\mathrm{D}(52$ 機)、 $\mathrm{E}(3$ 機)、F(1 機)で表現したものであ る。直流系に接続するC、D系統は此較的詳細に表現した。 また、発電機の制御系は比較的長時間のシミュレーション に対し忠実に応動するよう、AVR、PS S、スピードガ バナを詳細に模擬した。

長周期動摇モードを発生しやすいF 1 地点での $3 \mathrm{~L} \mathrm{G}$ 一O事故、C采統動摇モードを発生しやすいF 2 地点での $3 L G-O$ 事故について、シミュレーションを行なった。 図 1 のA系統、C 系統内の代表発電機の位相角変動、直流 電力の変動状況を図 10 に示す。効果指数 $\Lambda 、 \Theta$ も併せて 示す。

これらの結果からわかるように、雨動摇モードに対し、 極めて効果的に動摇を娍衰させていることがわかる。なお、 図 10 では電力動摇がいわゆる長周期及びC系統動摇モ 一ドしか見られないが、これは各連系系統内の代表発電機 の举動を示したためであり、図では省略しているが事故点 近傍の発電機にはもっと周期の短いローカル動摇モード が含まれている。

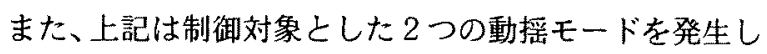
やすい事故について述べたものであるが、実システムでは、 電源脱落に伴う周波数変動現象やルート断を伴う事故等 に対してもPMが正常に動作することが必要で、詳細は省 くが、れらの事故に対しても解析を実施し、正常動作す るこよを確認している。

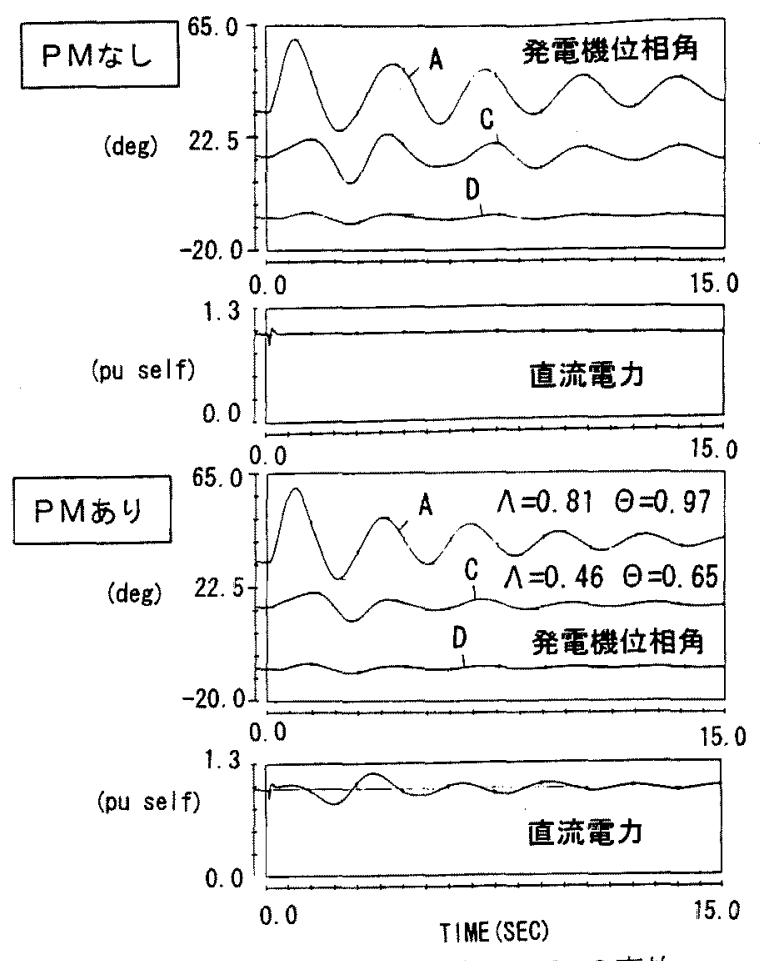

(a) F I 点 $3 \mathrm{~L} \mathrm{G}-\mathrm{O}$ 事故

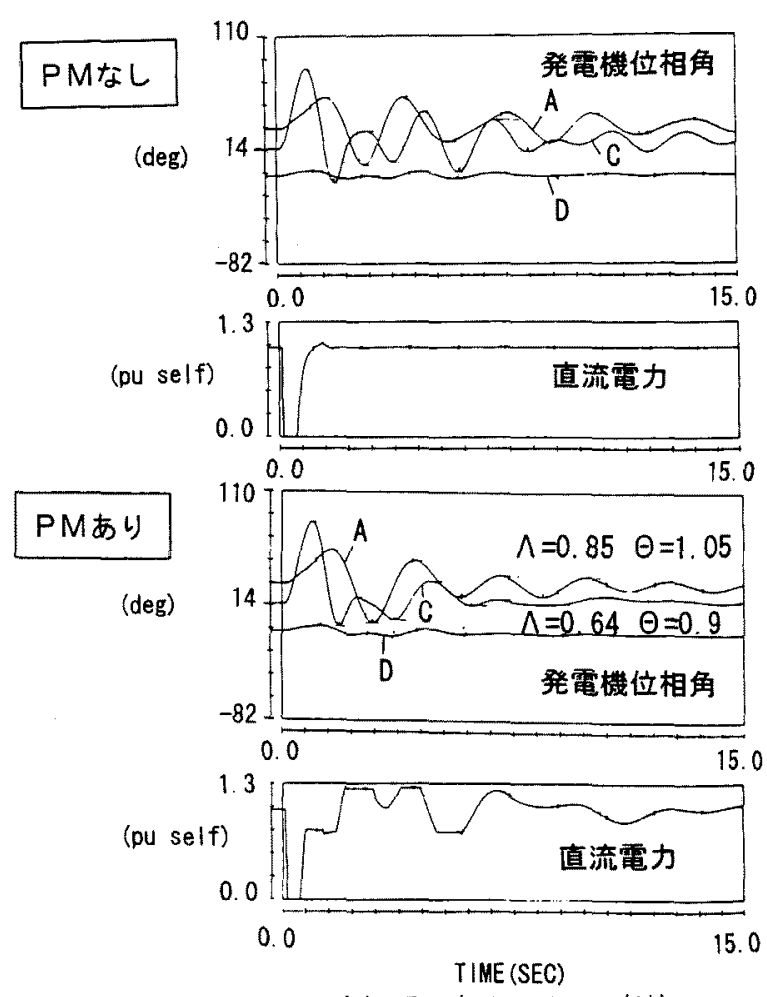

(b) F 2 点 $3 \mathrm{~L} \mathrm{G}-\mathrm{O}$ 事故

图 10 PM基本制御特性シジレーション結果

Fig. 10 Simulation Results of PM Fundamental Characteristics 


\section{2 系統解析シミュレータによる動作検証}

PM制御のアルゴリズム的な検証はディジタルシミュ レーションで十分検証出来るが、制御システム全体を考え れれば、電力動摇検出用の $\triangle \mathrm{f}$ 検出センサの特性等、ハー ドウエアの詳細特性を考虑した検証が必要である。このた め $\triangle \mathrm{f}$ 検出用センサを含めて $\mathrm{PM}$ の制御装置を試作し、ア ナログタイプの大規模系統解析シミュレータ (A P S A :

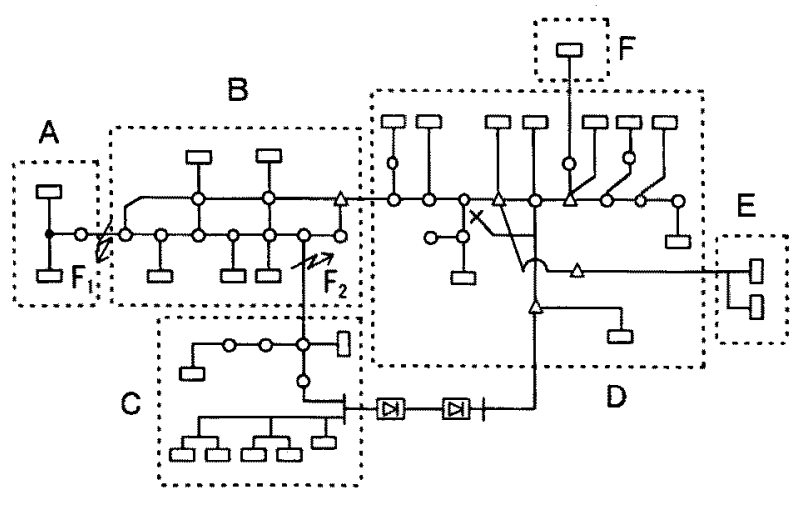

図 11 シミュレータ試験系統図

Fig. 11 Power System Model in Simulator Test

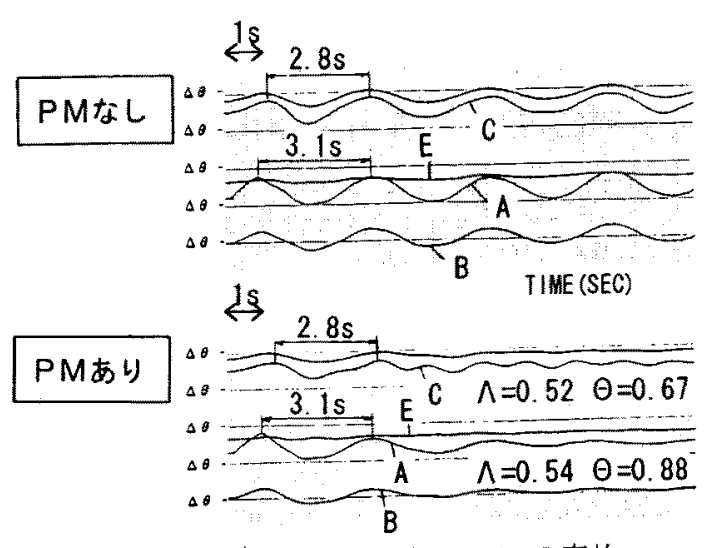

Is（a） F 1 点 $3 \mathrm{~L}$ G-O事故

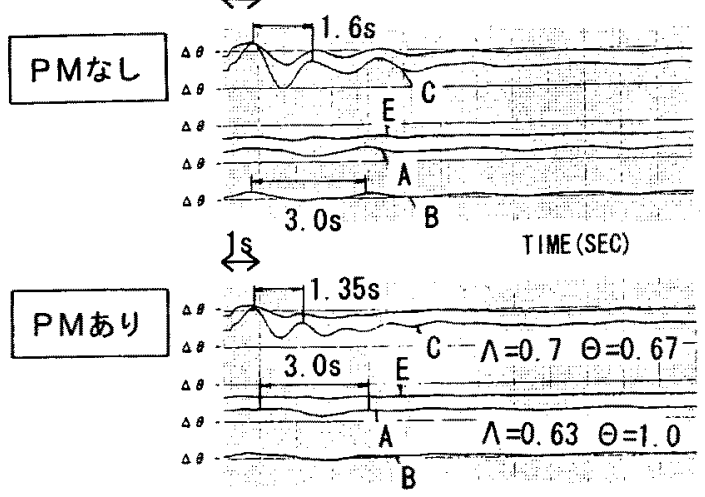

(b) $\mathrm{F} 2$ 点 $3 \mathrm{~L} \mathrm{G}-\mathrm{O}$ 事故

图 12 シミュレー夕試験結果

Fig. 12. Simulator Test Results
Advanced Power System Analyzer : 関西電力(株)総合技術研 究所)[6]を用いて、動作検証を行なった。シミュレータ設 備の制的から、ディジタルシミュレーションで検証した解 析系統(95機系) 28 機系に縮約してシミュレーショ ンを行なった（図11 参照）。

試験結果を図 12 に示す。試験ケースと評価はディジ夕 ルシミュレーションと同様に $F_{1}$ 点、 $F_{2}$ 点での $3 \mathrm{~L} \mathrm{G}-$ $\mathrm{O}$ 事故に対する $\mathrm{A}$ 系統、C 系統の代表発電機の電力動摇の 减衰に及估す効果評価を行なった。図からわかるように アナログ形のシミュレータ試験においても P M制御が動 摇㧕制に有効であることが確認できる。

なお、試作したP M制御装置はマイクロコンピュータを用 いたディジタル制御装置で構成した。装置構成のブロック 図を図 13 に示す。 $\Delta \mathrm{f}$ を入力信号とし、直流電力指令值 のモジュレーション信号 $\Delta \mathrm{P}_{\mathrm{dp}}$ を出力する。

$\mathrm{PM}$ 制御の入力信号として、 $\triangle \mathrm{f}$ 信号を用いる方式はア ルゴリズム的に優机ているが、 $\triangle \mathrm{f}$ 検出器の検出精度と分 解能に課題が予想されたが、シミュレー夕試駼結果から、

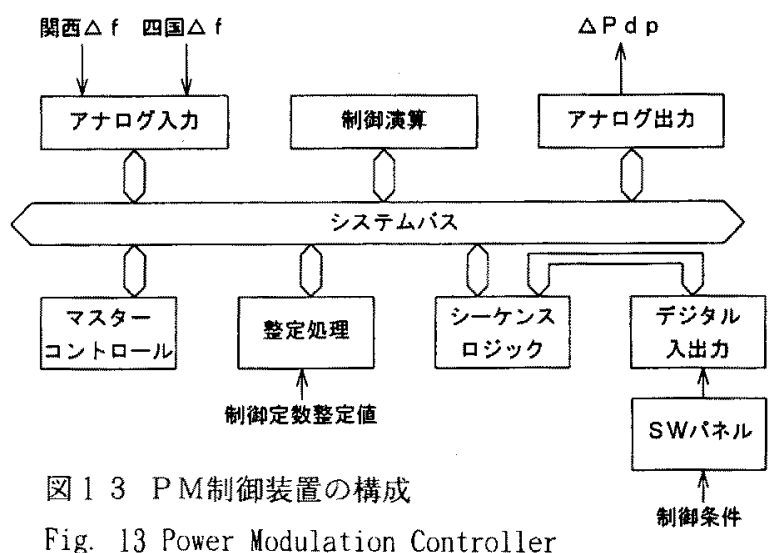

\section{入力電圧周波数 [Hz]}

$\begin{array}{llllllll}58 & 59 & 6 & 0 & 6 & 1 & 62\end{array}$

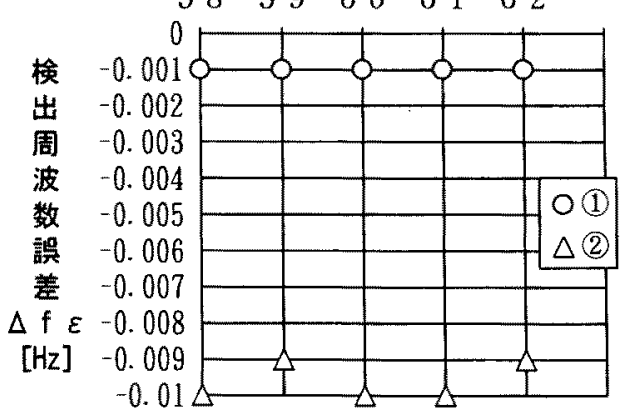

試験条件（入力信号への印加高調波成分）

ケース(1): 雾.

ケース(2): 3.5次、5\%重量

図 14 周波数検出器の特性

Fig. 14 Characteristics of Frequency Detector 
今回開発した $\triangle \mathrm{f}$ 検出器はこの課題を十分解決出来る事 が確認出来た。シミュレー夕試験に用いた $\triangle \mathrm{f}$ 検出器の特 性は図 14 に示す通りである。なお、シミュレー夕試験に おいて、 $\Delta \mathrm{f}$ 検出器に取り込む変換所母線電压の高調波， イズは総合電圧垔率が 0.8\%程度で、ほぼ実システムのレ ベルであった。

\section{5.まとめ}

直流送電電力のパワーモジュレーションにより系統の 電力動摇を抑制する制御方式について検討し、6 $0 \mathrm{~Hz}$ 系 における複数の動摇モードに対する制御方式を開発した。 制御方式、入力信号の特質と選択根拠、パワーモジュレー ション制御の起動・停止方式について述べるとともに、開 発したパワーモジュレーション制御方式についてディジ タルシミュレーションにより、その動摇抑制効果を検証し た。更に制御装置を試作しアナログ形の系統解析シミュレ 一夕と組合せて、 $\triangle \mathrm{f}$ 検出センサを含めたハードウエア特 性も含む総合試験を行ない、実システムにおいても十分そ の動摇抑制効果を発揮することを検証した。

最後に本研究を進めるにあたり、有益な御討論を頂いた (株) 電力計算センター竹中次長他に厚く御礼申し上げる。 (平成 8 年 10 月 25 日受付、同 9 年 2 月 19 日再受付)

\section{文 献}

[1] R.L. Cresap, D. N. Scott, W.A. Mittelstadt, C.W. Tailor "Operating Experience with Modulation of the Pacific HVDC Intertie" IEEE Trans. on Power Apparatus and Systems, Vol PAS-97, No. 4 July/August 1978

[2] J. Chand "Auxiliary Power Controls on the Nelson River HVDC Scheme" IEEE Trans. on Power Systems, Vol. 7, No. 1 February 1992

[3] L.A.S. Pilotto, M. Szechtman, A. Wey, W.F. Long, S.L Nilsson "Synchronizing and Damping Torque Modulation Controllers for Multi-Infeed HVDC Systems" IEEE Trans. on Power Delivery, Vol. 10, No. 3, July 1995

[4] Y.Sekine, S.Kato, T.Motoki, S.Ito "Kii Channel HVDC Link Between Shikoku and Kansai Electric Power Companies by Submarine Cables" CIGRE Tokyo Symposium, Paper No 220-04, May 1995
[5] T. Fujiwara, K. Matsuno, Y. Inoue and T. Hayashi "Study of Power Modulation and Fast Margin Angle Control in Kii Channel HVDC Link" CIGRE Tokyo Symposium, Paper No. 410-05, May 1995

[6]土井、後藤、河合、鈴木、横川：「大規模電力系統シ ユレータの開発」:電学論 B、 110 巻 9 号, 平成 2 年 9 月

富山 睠幸 （正員）' 63 年 4 月関西電力（株）入社。

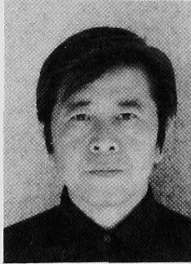
' 71 年 3 月姫路工業大学工学部電気工学 科卒業。現在、関西電力（株）総合技術 研究所流通設備研究室主席研究員。送変 電設備の計画、解析、シミュレータの運 用に従事。

佐藤 雅一

（正員） 1950 年 9 月 12 日生。' 71 年 3 月岐阜高専電気工学科卒業。同年 4 月関 西電力（株）入社。主として制御保護関 係業務に従事。現在、同社電力システム 室大電力送電チーム課長。

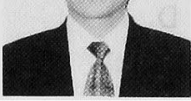

山地幸司（正員） 1950 年 2 月 11 日生。'73年 3 月

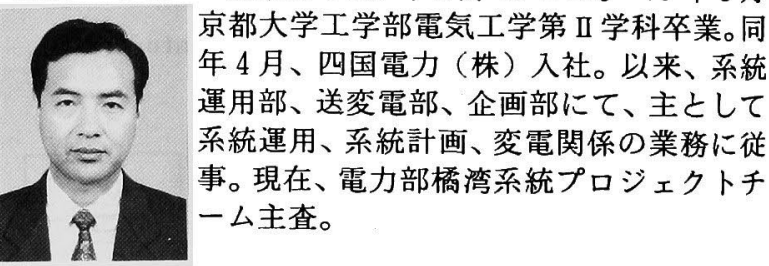

関田 昌弘（正員）1956 年 6 月 23 日生。' 81 年 3 月 東京大学工学部電気工学科卒業。同年 4 月、電源開発 (株) 入社。主に電力系統の
計画、解析業務に従事。現在、同社工務部

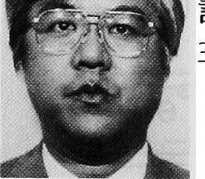

後藤 益雄 (正員) 1942 年 5 月 9 日生。' 65 年 3 月 大阪府立大学工学部電気工学科卒業。同年 4 月（株）日立製作所入社。日立研究所、 国分工場を経て、現在、同社電力事業部副 技師長。工学博士。主として電力系統の解 析業務と制御システムの開発、評価業務に 従事。昭和 45 年オーム技術賞受賞、平成 2 年度電気学会進歩賞受賞、CIGRE WG 14-27 委員、IEEE Fellow。 